\title{
Penilaian Daur Hidup (Life Cycle Assesment) Produk Kina Di PT Sinkona Indonesia Lestari
}

\author{
Pinkan Pangestu Parameswari ${ }^{1}$, Moh. Yani², dan Andes Ismayana ${ }^{2}$
}

1 Program Studi Ilmu Pengelolaan Sumberdaya Alam dan Lingkungan, Sekolah Pascasarjana, Institut Pertanian Bogor - pinkanpangestu5882@gmail.com

${ }^{2}$ Departemen Teknik Industri Pertanian, Fakultas Teknologi Pertanian, Institut Pertanian Bogor

\begin{abstract}
ABSTRAK
PT Sinkona Indonesia Lestari adalah anak perusahaan dari dua Badan Usaha Milik Negara yaitu PT Kimia Farma dan PT Perkebunan Nusantara VIII. PT Sinkona Indonesia Lestari (SIL) memproduksi cinchona atau yang dikenal dengan tanaman kina yang merupakan tanaman obat yang mengandung quinine yang dikenal sebagai obat malaria. Cinchona diekstraksi untuk diambil kandungan quinine. Setiap tanaman cinchona mengandung kadar quinine 3-14\%. Penilaian jumlah emisi yang dikeluarkan selama proses produksi dapat dilakukan dengan menggunakan metode Life Cycle Assessment (LCA). Selain itu, LCA juga akan digunakan untuk melakukan perbaikan dalam siklus hidup produksi yang bertujuan untuk mengurangi emisi. Tujuan penelitian ini adalah untuk menilai dampak lingkungan berupa gas rumah kaca (GRK), serta upaya untuk mengurangi dampak lingkungan tersebut. Tahapan dari penelitian ini adalah menentukan tujuan dan ruang lingkup, analisis inventori daur hidup, analisia penilaian dampak lingkungan, dan analisis interpretasi hasil. Dari analisis LCA, untuk menghasilkan 1 ton garam kina diketahui menghasilkan dampak lingkungan berupa emisi gas rumah kaca sebesar 47.3815 $\mathrm{CO}_{2}(\mathrm{eq})$ pada tahun 2013. Pada tahun 2014 emisi gas rumah kaca mengalami penurunan sebesar 53.4217 $\mathrm{CO}_{2}$ (eq). Pada 2015, 1 ton garam kina menghasilkan emisi gas rumah kaca sebesar 53.5435 $\mathrm{CO}_{2}$ (eq) dan pada 2016 menghasilkan $45.7901 \mathrm{CO}_{2}(\mathrm{eq})$. Penelitian ini juga menemukan bahwa pemanfaatan ampas kina dan penggantian minyak residu menjadi bahan bakar solar dapat mengurangi emisi. Pembuatan briket dari ampas kina dapat menurunkan emisi gas rumah kaca sebesar 0,14 \% pada tahun 2015 dan menghasilkan energi alternatif sebesar 1.612 TJ. Alternatif lain adalah penggantian minyak residu menggunakan bahan bakar solar (ID0) pada bahan bakar boiler, yang dapat mengurangi emisi sebesar $11.9 \%$ atau 6.3518 ton $\mathrm{CO}_{2}(\mathrm{eq}) /$ ton garam kina.
\end{abstract}

Kata kunci: Tanaman Kina, Emisi, Gas Rumah Kaca, Penilaian Daur Hidup Produk, Kinin

\begin{abstract}
PT Sinkona Indonesia Lestari is a subsidiary of two State-Owned Enterprises namely PT Kimia Farma and PT Perkebunan Nusantara VIII. PT Sinkona Indonesia Lestari (SIL) produces quinine from cinchona which is medicinal plants containing quinine which known as a malaria medicine. Chincona is extracted to produce quinine. Each chincona plant contains quinine levels of 3-14\%. Assessment of the amount of emissions issued during quinine production could be done using the Life Cycle Assessment (LCA) method. In addition, LCA also would be used to make improvements in the life cycle of quinine production that aimed to reduce emissions The objective of research was to asses the environmental impacts of greenhouse gases, as well as efforts to reduce these environmental impacts. The research stages were goal and scope definition, life cycle inventory analysis, life cycle impact assessment, and life cycle interpretation. From the LCA analysis, it was known to produce 1 ton of quinine salt, the environmental impact on greenhouse gas emissions 47.3815 $\mathrm{CO}_{2}$ (eq) in 2013, in 2014 greenhouse gas emissions decreased. by $53.4217 \mathrm{CO}_{2}(\mathrm{eq})$. In 2015, 1 ton of quinine salt produced greenhouse gas emissions of $53.5435 \mathrm{CO}_{2}(\mathrm{eq})$ and in 2016 produced $45.7901 \mathrm{CO}_{2}(\mathrm{eq})$. This research found that utilization from quinine pulp and subtitution residual oil with diesel could reduce emisssion. For making of briquettes from quinine pulp can reduce $0.18 \%$ greenhouse gas emission in 2013 and produce alternative energy of $2.87 \mathrm{TJ}$. Another alternative was the replacement of residual oil by using diesel fuel (IDO) on boiler fuel, that could reduce emissions by $7.4 \%$ or 3.187 tons of $\mathrm{CO}_{2}(\mathrm{eq}) /$ ton of quinine salt.
\end{abstract}

Keywords: Cinchona, emission, greenhouse gas, life cycle assessment, quinine

Citation: Parameswari, P. P., Yani, M., dan Ismayana, A. (2019). Penilaian Daur Hidup (Life Cycle Assesment) Produk Kina Di PT Sinkona Indonesia Lestari. Jurnal Ilmu Lingkungan, 17(2), 351-358, doi:10.14710/jil.17.2.351-358 


\section{Latar Belakang}

Cinchona atau lebih sering dikenal dengan nama pohon kina merupakan tanaman yang berasal dari Bolivia dan Peru yang dapat tumbuh di Indonesia. Kina (Quinine) diketahui memiliki kadar kinin yang tinggi yaitu 4 - 13\%. Kinin digunakan sebagai obat antimalaria, sedangkan kinidin selain digunakan sebagai obat antimalaria juga dapat digunakan sebagai obat untuk menormalkan denyut jantung yang tidak teratur (cardiac arythmic) (Zustika 2013). Pohon kina diambil kulitnya. Kulit kina diekstraksi untuk memproduksi garam kina yang digunakan sebagai obat.

Di Indonesia, salah satu industri yang memproduksi kina menjadi garam kina adalah PT Sinkona Indonesia Lestari (SIL). PT SIL merupakan anak perusahaan dari dua Badan Usaha Milik Negara yaitu PT Kimia Farma dan PT Perkebunan Nusantara VIII. Pabrik pengolahan kina berlokasi di Jalan Raya Ciater, Kabupaten Subang, Jawa Barat. PT SIL memproduksi garam kina untuk dijual di dalam negeri maupun diekspor.

PT SIL dapat menghasilkan 500-600 kg garam kina/hari. Pada tahun 2012, kemampuan produksi garam kina PT SIL naik menjadi 150 ton/tahun dari yang sebelumnya 100 ton/tahun. Produksi yang semakin meningkat dikarenakan permintaan pasar yang terus meningkat. Di Cina misalnya, PT SIL memegang pangsa pasar lebih dari 50\%. Indonesia kembali menjadi salah satu produsen terbesar dunia pada tahun 2013 (Disbun 2013).

Pada tahun 2016, luas lahan yang ditanami kina adalah 683 hektar, terdiri dari 214 hektar adalah lahan yang ditanami oleh tanaman muda dan 469 hektar adalah lahan menghasilkan. Hasil produksi dari tanaman kina sendiri adalah sebesar 71 ton/tahun (BPS Jabar 2018).

Kegiatan industri tentu akan berdampak pada perubahan lingkungan, seperti perubahan kualitas air, tanah, dan udara. Untuk mengurangi pencemaran dan dampak lingkungan yang ditimbulkan selama siklus hidup produk, metode yang tepat untuk menganalisis adalah metode life cycle assessment (LCA). Analisis LCA bertujuan untuk menghitung beban lingkungan berdasarkan analisis inventori dari penggunaan sumberdaya, energi, air, bahan bakar, dan lainnya sehingga dapat diketahui beban lingkungan yang ditimbulkan kemudian dilakukan analisis menggunakan alternatif yang berbeda untuk mengurangi dampak yang ditimbulkan (Purwaningsih 2016).

Pada penelitian Purwaningsih 2016 pada industri gula dilakukan penilaian LCA, didapatkan total gas rumah kaca yang dihasilkan dalam proses produksi gula pada tahun 2014 adalah sebesar 14195.932 ton $\mathrm{CO}_{2}(\mathrm{eq})$. Dampak yang terjadi menghasilkan alternatif-alternatif perbaikan yang dapat dilakukan untuk mengurangi dampak lingkungan.

Menurut Perpres 61 tahun 2011 tentang Penyelenggaraan Inventaris Gas Rumah Kaca di bidang pertanian dan perkebunan memiliki target penurunan GRK sebesar 0.008 Giga Ton $\mathrm{CO}_{2}$ e pada skenario $26 \%$ dan 0.011 Giga Ton $\mathrm{CO}_{2}$ e pada skenario 41\%. Untuk konsisten membantu pemerintah dalam penurunan emisi perlu dilakukan perhitungan sebesar apa dampak yang dihasilkan dalam produksi perkebunan terutama kina, sehingga dapat mengurangi dampak itu sendiri. Selain itu, belum adanya penelitian LCA tentang kina dan indutri pengelolaannya merupakan salah satu permasalahan yang terjadi. Masih kurangnya informasi tentang penelitian tentang proses produksi kina.

Pada LCA dibutuhkan data mengenai input dan output secara lengkap, meliputi bahan baku, proses pembuatan, distribusi, transportasi, konsumsi, hasil samping dan dampak ligkungan. LCA terdiri dari beberapa elemen, di antaranya; (1) identifikasi dan mengukur faktor-faktor yang terlibat, (2) evaluasi faktor-faktor yang berpotensi berdampak terhadap lingkungan, dan (3) analisis untuk mengurangi dampak lingkungan (Mattson dan Sonesson 2003; Ekvall dan Weidema 2004). Analisis LCA dapat menjadi alternatif sebagai upaya meminimalisasi limbah dan pengelolaan limbah di pabrik. Pengurangan jumlah limbah dan pengelolaannya akan memberikan dampak luas terhadap tingkat produktivitas dari industri. (Lin et al. 2009).

Pada penelitian ini dilakukan penilain LCA produksi garam kina selama proses dampak lingkungan dari masing-masing jenis unit proses. Sehingga, dari hasil analisis aliran material, energi yang dibutuhkan, dan emisi pada masing-masing unit proses dapat diperoleh secara detail unit proses mana yang memiliki dampak lingkungan terbesar Dengan mengetahui besar dampak lingkungan yang dihasilkan maka dapat dilakukan upaya perbaikan dengan mengidentifikasi tahapan proses yang paling signifikan terhadap dampak lingkungan yang dapat dilakukan dengan cara 3R (reuse, reduce, recycle) terhadap limbah yang dihasilkan, serta melakukan kajian pengelolaan limbah yang dapat dimanfaatkan sebagai energi alternatif.

Berdasarkan uraian diatas didapat tujuan dari penelitian ini adalah :

1. Mengidentifikasi dan menganalisis input output berdasarkan data inventori dari produk kina.

2. Menganalisis potensi dampak lingkungan berupa gas rumah kaca (GRK).

3. Menganalisis alternatif perbaikan dalam upaya penurunan dampak lingkungan.

\section{Metode}

Metode LCA dilakukan berdasarkan Principles and Framework LCA yang ada pada 14040:2006a yang terdiri dari 4 tahap, yaitu definisi tujuan dan ruang lingkup (goal and scope definition), analisis inventori (life cycle inventory analysis), analisis dampak lingkungan (life cycle impact assessment), dan interpretasi hasil (life cycle interpretation). 


\subsection{Tujuan dan ruang lingkup}

Goal and scope definition merupakan tahap awal dalam melakukan analisis LCA. Pada tahap ini dibuat dan ditentukan tujuan dari kajian LCA serta menentukan batasan atau ruang lingkup dalam pelaksanaan LCA. Pada pembuatan tujuan dinyatakan maksud dari aplikasi LCA, alasan dilakukannya studi LCA, target audien yang menerima hasil LCA, dan yang terakhir penggunaan LCA sebagai perbandingan pada berbagai kasus yang dilakukan (ISO 2006b).

Setelah tujuan ditentukan dilanjutkan dengan penentuan ruang lingkup LCA. Hal pertama pada penentuan ruang lingkup adalah menentukan function, functional unit dan reference flow dari sistem (ISO 2006b). Functional unit yang digunakan pada penelitian ini adalah sebesar 1 ton garam kina yang dihasilkan oleh sistem produksi kina. Hal kedua yang dilakukan dalam pembuatan ruang lingkup adalah penentuan batasan sistem. Pembatasan sistem pada penelitian ini menggunakan pembatasan cradle to gate dari budi daya kina hingga produksi kina.

\subsection{Analisis inventori}

Analisis inventori merupakan bagian dari LCA yang berisi satu set data dan perhitungan aliran bahan dan energi yang mengkuantifikasi input dan output dari daur hidup garam kina. Dalam penelitian ini, data yang digunakan berasal dari data sekunder berupa data kebutuhan energi, bahan baku, dan limbah yang dihasilkan. Sebagian data diperoleh dari hasil perhitungan dengan beberapa asumsi dan data primer. Berdasarkan hasil analisis inventori diperoleh besaran kebutuhan bahan baku, energi dan emisi yang dihasilkan untuk memproduksi satu ton garam kina.

\subsection{Analisis dampak lingkungan}

Penilaian dampak lingkungan dilakukan sesuai dengan goal and scope definition yang telah ditentukan. Pada GRK yang dihasilkan di industri kina, dianalisis berdasarkan kandungan $\mathrm{CO}_{2}, \mathrm{~N}_{2} \mathrm{O}$, dan $\mathrm{CH}_{4}$ yang dikonversi menjadi $\mathrm{CO}_{2}$-eq. Perubahan konversi setiap dampak lingkungan GRK, setiap $1 \mathrm{~kg}$ $\mathrm{CH}_{4}$ sama dengan $25 \mathrm{~kg} \mathrm{CO}$-eq, sedangkan setiap 1 $\mathrm{kg} \mathrm{N}_{2} \mathrm{O}$ bernilai $298 \mathrm{~kg} \mathrm{CO}$-eq (KLH 2012). Contoh rumusan perhitungan dampak lingkungan dapat dilihat pada tabel 1 .

Tabel 1. Rumusan Perhitungan Dampak Lingkungan

\begin{tabular}{|c|c|c|c|}
\hline Dampak Lingkungan & Perhitungan & Rumusan & Sumber \\
\hline Gas Rumah Kaca & $\begin{array}{l}\text { Bahan Bakar } \\
\text { Listrik } \\
\text { Pembakaran Plastik } \\
\text { Limbah Cair } \\
\text { Bahan Bakar } \\
\text { Pembakaran Plastik } \\
\text { Pupuk } \\
\text { Serasah } \\
\text { Bahan Bakar } \\
\text { Pembakaran Plastik } \\
\end{array}$ & 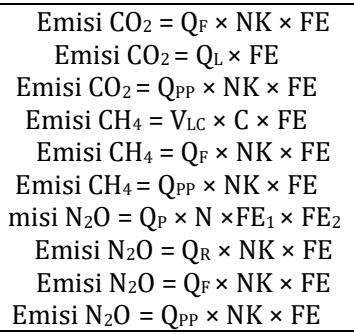 & $\begin{array}{l}\text { IPCC (2006) } \\
\text { Putt dan Bhatia (2002) } \\
\text { IPCC (2006) } \\
\text { IPCC (2006) } \\
\text { IPCC (2006) } \\
\text { IPCC }(2006) \\
\text { IPCC }(2006) \\
\text { IPCC }(2006) \\
\text { IPCC }(2006) \\
\text { IPCC }(2006)\end{array}$ \\
\hline
\end{tabular}

Keterangan :

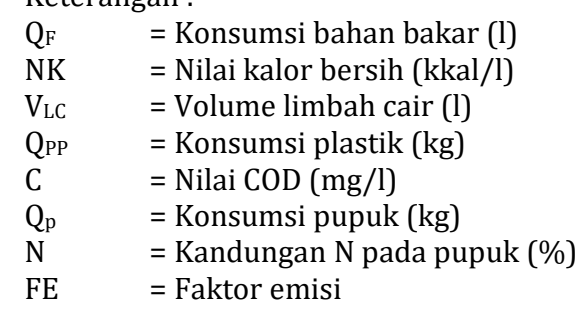

\subsection{Analisis interpretasi hasil}

Interpretasi hasil adalah langkah terakhir dalam LCA. Interpretasi hasil terdiri dari dua langkah, yaitu identifikasi isu penting dan evaluasi. Pada tahap identifikasi isu penting, interpretasi hasil dilakukan untuk melihat konsistensi dalam invetarisasi input, output, dan penilaian dampak lingkungan. Pada tahap ini akan ditentukan bagian dari proses yang perlu/dapat dilakukan upaya penurunan emisi. Data yang digunakan dalam penelitian ini terdiri dari data wawancara langsung dengan karyawan pabrik, dokumen perusahaan selain itu juga data dari penelitian sebelumnya yang relevan.

\section{Hasil dan Pembahasan 3.1 Tujuan dan ruang lingkup}

Goal (tujuan) dari studi ini adalah untuk menganalisis daur hidup produk garam kina selama proses pengolahan dengan metode penilaian daur hidup produk, di antaranya identifikasi input (resources) dan output (emisi dan produk) berdasarkan data inventori di pabrik garam kina. Scope (ruang lingkup) studi penilaian daur hidup produk ini meliputi budidaya tanaman kina dari kebun, transportasi, hingga proses produksi garam kina di pabrik. Batasan sistem penelitian yang diamati diilustrasikan dalam gambar 1 . Function pada studi ini adalah pembuatan garam kina di pabrik dengam functional unit 1 ton garam kina yang dihasilkan oleh pabrik.

Setiap tahapan proses memerlukan sumber daya energi dalam prosesnya, disamping menghasilkan produk itu sendiri dalam prosesnya juga dapat menghasilkan emisi. Dalam melakukan kajian ini, analisi dampak yang dihasilkan hanya mencakup dampak terhadap emisi gas rumah kaca, serta digunakan perbandingan kajian LCA selama 4 tahun yaitu 2013-2016 untuk melihat dampak yang 
dihasilkan dengan perbedaan sumber daya yang digunakan..

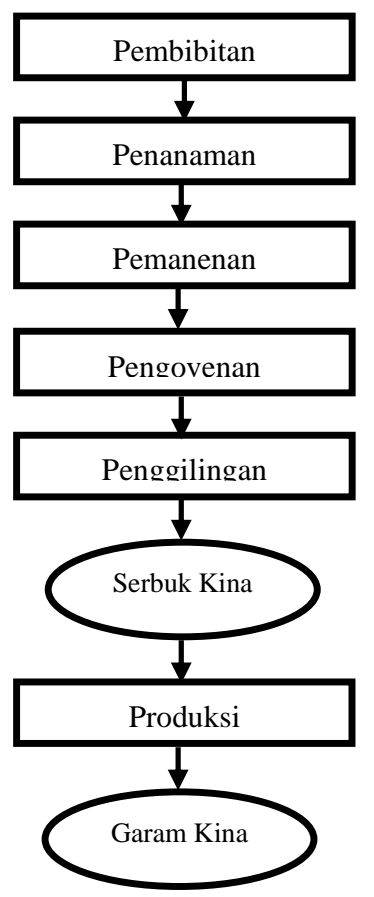

Gambar 1 Ruang Lingkup Penelitian

\subsection{Analisis inventori}

\section{Budi Daya}

Pembibitan kina di PTPN VIII dilakukan 4-5 tahun sekali. Proses pembibitan tanaman kina dilakukan terjadi selama setahun lamanya. Dimulai dari penyiapan lahan pada bulan april hingga juli. Penyiapan lahan dilakukan dengan cara membersihkan gulma dan alang alang di lahan pembibitan. Kemudian dilakukan pengayakan tanah organik, yang nantinya sebagai media pembibitan. Penyiapan luas lahan disesuaikan dengan rencana jumlah pembibitan. Pada tahun 2013, PTPN VIII melakukan pembibitan sebanyak 600000 bibit.

Lahan yang telah dibersihkan dibagi-bagi membentuk bedeng-bedeng berukuran $10 \mathrm{~m} \mathrm{x} 1 \mathrm{~m}$ dengan kedalaman $40 \mathrm{~cm}$. Nantinya bedeng-bedeng ini akan diletakkan bibit-bibit tanaman kina yang telah disetek sambung dari tunas tanaman kina, yang mana pada bagian bawah berupa tanaman kina jenis suchilubra dan bagian atas adalah tanaman kina jenis ledgeriana. Setiap bibit pohon kina yang telah disetek, nantinya akan dimasukkan ke dalam plastik berukuran 12 × $25 \mathrm{~cm}$. Dalam satu bedeng biasanya diletakkan 1000 bibit pohon kina.

Selama dalam pembibitan, 3 bulan pertama akan dilakukan adaptasi dari hama penyakit. Setelah 3 bulan bibit kina nantinya akan dirawat dengan pemberian pupuk sebanyak 3 kali aplikasi selama satu tahun pembibitan. Penggunaan pupuk NPK, ZA dan Urea dengan dosis masing masing $3: 1: 1$. Bibit yang telah berumur minimal 12 bulan siap untuk dipindahkan penanaman ke lahan yang telah dipersiapkan.

Penanaman dilakukan saat kelembapan relatif harian minimum adalah sebesar $68 \%$ - 97\%. Ukuran kedalaman lubang tanam adalah $60 \mathrm{~cm}$ dengan lebar $20 \mathrm{~cm}$ jarak antar tanaman $1 \mathrm{~m}$. Tidak ada banyak perawatan yang dilakukan oleh PTPN VIII setelah tanaman ditanam.

Lokasi penanaman terjauh dibantu pengangkutan bibit dengan menggunakan truk. Truk berbahan bakar solar berkapasitas 5000 bibit pohon. Pohon yang sudah ditanam dapat dipanen kemudian diambil kulitnya ketika sudah berumur 7 tahun dengan diameter pohon sekitar 7-10 cm. Biasanya dalam 1 pohon kina terdapat 3 batang kina yang dapat diambil. Pemanenan dilakukan dengan cara menebang salah satu batang kina, batang kedua boleh ditebang setelah 1 tahun batang kina pertama ditebang, begitu pula dengan batang ketiga. Nantinya kina yang sudah ditebang akan timbul tunas baru yang akan tumbuh menjadi batang batang kina yang siap dipanen setelah 5 tahun. Setiap batang kina biasanya dipanen 3 kali, setelah itu pohon akan ditebang habis hingga diganti dengan tanaman baru.

Tabel 2. Data inventori budi daya kina di PTPN VIII 2013-2016

\begin{tabular}{lcrrrr} 
& \multirow{2}{*}{ Data } & Satuan & \multicolumn{5}{c}{ Tahun } \\
\cline { 3 - 6 } Input & & & \multicolumn{1}{c}{2014} & \multicolumn{1}{c}{2015} & 2016 \\
Bibit Kina & bibit & 600000 & & & \\
Tanaman Kina & pohon & & 300000 & 300000 & \\
Solar Kebun & liter & & 342.86 & 342,86 & \\
Solar BU - SIL & liter & 239.14 & 199.29 & 225.86 & 124.00 \\
Air & $\mathrm{m}^{3}$ & 22 & 58.2 & 58.2 & \\
Listrik & $\mathrm{kWh}$ & 8188 & 7009 & 7863 & 4331 \\
Polybag & ton & & 0.501 & 0.501 & \\
Batang Kayu & ton & 343.70 & 252.21 & 332.95 & 187.29 \\
NPK & ton & 1.08 & & & \\
Urea & ton & 0.36 & & & \\
Za & ton & 0.36 & & & \\
Output & & & & & \\
Serbuk Kulit Kina & ton & 133.63 & 114.67 & 128.29 & 70.65 \\
Serasah & ton & 3.66 & 2.69 & 3.54 & 1.99 \\
\hline
\end{tabular}


Batang kina yang telah dipanen akan dipukul pukul menggunakan palu kayu untuk diambil kulitnya.. Kulit kina yang telah terkumpul dari para pengumpul, dibawa ke bagian proses pengerimgan untuk ditimbang kemudian dijemur. Sedangkan batang kina yang telah dikuliti, nantinya akan dikumpulkan untuk digunakan sebagai bahan bakar diproses pengovenan.

Kulit kina yang telah dipanen kemudian dibawa ke tempat pengeringan, kulit kina akan dijemur hingga kadar air 46\%. Penjemur dilakukan selama 10-21 hari tergantung cuaca dan panas matahari. Kulit kina yang sudah dijemur, akan dioven selama 8 jam sampai kadar air dibawah 12\%.

Tempat pengovenan berkapasitas 1 ton kulit kina, dan membutuhkan $8 \mathrm{~m}^{3}$ kayu bakar. Kayu bakar terdiri dari kayu tanaman kina hasil pengulitan dan beberapa jenis kayu bakar lainnya. Kulit kina kering akan digiling menjadi kulit kina kasar menggunakan alat gilingan yang memiliki daya $20 \mathrm{kVA}$. Untuk 1 ton kulit kina kering membutuhkan waktu 3 jam pengilingan. Serbuk kina akan dikemas menggunakan karung berukuran $50 \mathrm{~kg}$. Serbuk kina yang telah dikemas siap diantar ke PT SIL.

Serbuk kulit kina kemudian diangkut menggunakan mobil truk berkapasitas 5 ton serbuk kina. Lokasi jarak PTPN VIII dengan PT SIL adalah 31 $\mathrm{km}$. Penentuan jarak angkut dari kebun ke pabrik menggunakan google map. Data inventori budi daya kina di PTPN VIII dapat dilihat pada Tabel 2.

\section{Produksi}

Proses produksi garam kina dilakukan oleh PT SIL. Proses produksi garam kina pada hakekatnya adalah memisahkan kina yang terkandung untuk kemudian diubah menjadi garam kina. Proses dimulai dari penggilingan, ekstraksi, destilasi, penggaraman, pemurnian hingga pengemasan. Data inventori proses produksi di PT SIL dapat dilihat pada tabel 3 .

Tabel 3. Data inventori produksi kina PT SIL tahun 2013-2016

\begin{tabular}{|c|c|c|c|c|c|}
\hline \multirow{2}{*}{ Data } & \multirow{2}{*}{ Satuan } & \multicolumn{4}{|c|}{ Tahun } \\
\hline & & 2013 & 2014 & 2015 & 2016 \\
\hline \multicolumn{6}{|l|}{ Input } \\
\hline Serbuk Kina & ton & 133.63 & 114.67 & 128.29 & 70.65 \\
\hline Air & liter & 70.83 & 66.06 & 66.84 & 85.30 \\
\hline Listrik Pabrik & $\mathrm{kWh}$ & 94665 & 74296 & 79173 & 47659 \\
\hline Listrik non Pabrik & kWh & 39870 & 44567 & 50240 & 45210 \\
\hline Minyak Residu & liter & 56116.1 & 46839.5 & 52450.5 & 27909.8 \\
\hline Solar boiler & liter & 504.19 & 364.8 & 356.3 & 361.4 \\
\hline Fiber Drum & buah & 203 & 165 & 212 & 112 \\
\hline Limbah Cair & $\mathrm{m}^{3}$ & 0.160 & 0.172 & 0.237 & 0.126 \\
\hline Sludge & $\mathrm{m}^{3}$ & 1.38 & 2.45 & 3.16 & 1.53 \\
\hline $\mathrm{NaOH}$ & ton & 6.928 & 5.251 & 6.055 & 3.088 \\
\hline $\mathrm{Na}_{2} \mathrm{SO}_{4}$ & ton & 0.353 & 0.165 & 0.482 & 0.319 \\
\hline $\mathrm{H}_{2} \mathrm{SO}_{4}$ & liter & 6.214 & 4.556 & 4.959 & 2.527 \\
\hline $\mathrm{HCl}$ & ton & 2.488 & 1.793 & 1.992 & 1.121 \\
\hline $\mathrm{NaCl}$ & ton & 1.16 & 0.811 & 0.919 & 0.518 \\
\hline Toluen $\left(\mathrm{C}_{7} \mathrm{H}_{8}\right)$ & liter & 59.660 & 44.570 & 42.020 & 24.019 \\
\hline \multicolumn{6}{|l|}{ Output } \\
\hline Garam Kina & ton & 5.98 & 4.95 & 5.40 & 3.11 \\
\hline Ampas Kina & ton & 128.72 & 84.5 & 125.06 & 67.56 \\
\hline
\end{tabular}

Pada tahap pertama dilakukan proses penggilingan kulit kina, menjadi serbuk kina. Penggilingan bertujuan untuk menyamakan ukuran serbuk kina sebelum dilakukan proses selanjutnya yaitu ekstraksi. Proses ekstraksi adalah suatu proses yang dilakukan untuk memperoleh kandungan senyawa kimia dari jaringan tumbuhan maupun hewan dengan pelarut yang sesuai dalam standar prosedur ekstraksi (Ditjen POM 2000). Dimana pelarut yang dipakai dalam proses ekstraksi kina adalah toluene $\mathrm{C}_{7} \mathrm{H}_{8}$. Dalam proses ini terjadi pemisahan antara kina yang terkandung di dalam serbu kina. Selain menghasilkan kina, dalam proses ini menghasilkan produk sampingan berupa limbah padat yaitu ampas kina.

Proses selanjutnya adalah proses destilasi. Destilasi atau penyulingan adalah suatu metode pemisahan bahan kimia didasarkan pada perbedaan kecepatan atau kemudahan menguap (volalitas) pada suhu tertentu (Syukri 2007). Pada proses kristalisasi dilakukan penambahan $\mathrm{NaOH}$ sehingga menghasilkan Kina Base. Kina Base kemudian di campur dengan $\mathrm{N}_{2} \mathrm{SO}_{4}$. Proses ini juga menghasilkan air limbah untuk diolah lebih lanjut. Suhu didalam proses ini adalah $80^{\circ}-82^{\circ} \mathrm{C}$.

Kina base yang dihasilkan akan dilakukan pemurnian. Kina base yang masuk ke dalam pemurnian masih mengandung toluene. Untuk memisahkan kina base dengan toluene dalam proses ini ditambahkan $\mathrm{HCl}$. Kina base yang telah terpisah dengan toluene disebut dengan Kina $\mathrm{HCl}$. Kina $\mathrm{HCl}$ nantinya akan ditambahkan dengan $\mathrm{NaCl}$ dan karbonaktif. Hasilnya akan keluar garam kina yang 
telah putih bersih siap untuk dikemas dalam fiber drum berukuran $25 \mathrm{Kg}$.

\subsection{Analisis Dampak}

Analisis dampak lingkungan digunakan untuk menganalisis dampak suatu proses terhadap lingkungan. Data analisa dampak dilakukan perhitungan secara kuantitatif berdasarkan data inventori menunjukan bahwa dalam setiap tahapan proses dapat menghasilkan limbah maupun emisi yang berdampak terhadap lingkungan. Analisis dampak total GRK garam kina pada setiap proses produksi di PT SIL dapat dilihat pada Tabel 4.

Tabel 4. Hasil analisis GRK garam kina 2013-2016

\begin{tabular}{|c|c|c|c|c|c|c|}
\hline \multirow{2}{*}{ Sumber } & \multirow{2}{*}{ Kategori } & \multirow{2}{*}{ Satuan } & \multicolumn{4}{|c|}{ Tahun } \\
\hline & & & 2013 & 2014 & 2015 & 2016 \\
\hline \multirow[t]{3}{*}{ Budi Daya Kina } & $\mathrm{CO}_{2}$ & ton $\mathrm{CO}_{2}$-eq/tahun & 4.6438 & 48.2420 & 48.7309 & 2.4493 \\
\hline & $\mathrm{N}_{2} \mathrm{O}$ & ton $\mathrm{CO}_{2}$-eq/tahun & 24.0336 & 0.4743 & 0.4757 & 0.0061 \\
\hline & $\mathrm{CH}_{4}$ & ton $\mathrm{CO}_{2}$-eq/tahun & 0.0023 & 0.1018 & 0.0988 & 0.0012 \\
\hline \multirow[t]{2}{*}{ Produksi Garam } & $\mathrm{CO}_{2}$ & ton $\mathrm{CO}_{2}$-eq/tahun & 253.8613 & 215.1978 & 239.1864 & 139.4723 \\
\hline & $\mathrm{N}_{2} \mathrm{O}$ & ton $\mathrm{CO}_{2}$-eq/tahun & 0.4349 & 0.3766 & 0.4193 & 0.2309 \\
\hline Kina & $\mathrm{CH}_{4}$ & ton $\mathrm{CO}_{2}$-eq/tahun & 0.5032 & 0.1546 & 0.1726 & 0.0935 \\
\hline Total & & ton $\mathrm{CO}_{2}-\mathrm{eq} /$ tahun & 283.4791 & 264.5471 & 289.0838 & 142.2532 \\
\hline Garam Kina & & ton/tahun & 5.98 & 4.95 & 5.4 & 3.11 \\
\hline $\begin{array}{l}\text { Dampak GRK } \\
\text { Per ton garam kina }\end{array}$ & & ton $\mathrm{CO}_{2}-\mathrm{eq} / \mathrm{ton}$ & 47.3815 & 53.4217 & 53.5435 & 45.7901 \\
\hline
\end{tabular}

Berdasarkan hasil yang ditunjukan pada Tabel 4, emisi gas rumah kaca (GRK) tertinggi terletak pada tahun 2015 yaitu sebesar 289.0838 ton $\mathrm{CO}_{2}$-eq /tahun atau 53.5435 ton $\mathrm{CO}_{2}$-eq/ton garam kina. Ditahun 2014 dan 2015 dilakukan penanaman kina, sehingga menghasilkan limbah plastik, yang kemudian dibakar. Perlakuan ini menyebabkan besarnya emisi GRK pada tahun tersebut.. apabila dilihat tahun 2016, emisi GRK per ton garam kina menurun, yaitu 45.7406 ton $\mathrm{CO}_{2}$-eq/ton garam kina.
Hal itu disebabkan juga, penurunan produksi kulit kina di PTPN VIII. Untuk melihat data analisis dampak GRK berdasarkan sumber dapat dilihat pada Tabel 5.

Menururt IPCC (2006), gas-gas utama yang dikategorikan sebagai GRK dan mempunyai potensi menyebabkan pemanasan global adalah $\mathrm{CO}_{2}, \mathrm{CH}_{4}$, dan $\mathrm{N}_{2} \mathrm{O}$. Gas $\mathrm{CO}_{2}$ mempunyai persentase sebesar $50 \%$ dalam total GRK, sementara $\mathrm{CH}_{4}$ memiliki persentase sebesar 20\% (Rukaesih 2004).

Tabel 5. Data analisis dampak GRK berdasarkan sumber emisi tahun 2013-2016

\begin{tabular}{|c|c|c|c|c|c|}
\hline \multirow{2}{*}{$\begin{array}{l}\text { Kategori } \\
\text { Polutan }\end{array}$} & \multirow{2}{*}{ Sumber GRK } & \multicolumn{4}{|c|}{ ton $\mathrm{CO}_{2}-\mathrm{eq}$} \\
\hline & & 2013 & 2014 & 2015 & 2016 \\
\hline \multirow[t]{5}{*}{$\mathrm{CO}_{2}$} & Solar & 0,3547 & 0,5197 & 0,4860 & 0,4468 \\
\hline & Listrik & 11,5698 & 12,3277 & 12,3316 & 15,1747 \\
\hline & Pembakaran Kayu & 0,0000 & 0,0000 & 0,0000 & 0,0000 \\
\hline & Minyak Residu & 31,2154 & 31,4789 & 32,3316 & 29,8992 \\
\hline & Pembakaran Plastik & 0,0000 & 8,7476 & 8,0234 & 0,0000 \\
\hline \multirow[t]{7}{*}{$\mathrm{N}_{2} \mathrm{O}$} & Solar & 0,0009 & 0,0082 & 0,0076 & 0,0070 \\
\hline & Pembakaran Kayu & 0,0000 & 0,0000 & 0,0000 & 0,0000 \\
\hline & Minyak Residu & 0,0721 & 0,0727 & 0,0747 & 0,0691 \\
\hline & Pembakaran Plastik & 0,0000 & 0,0908 & 0,0833 & 0,0000 \\
\hline & Pupuk & 4,0166 & 0,0000 & 0,0000 & 0,0000 \\
\hline & Serasah & 0,0002 & 0,0002 & 0,0002 & 0,0002 \\
\hline & Ampas Kina & 0,0673 & 0,0534 & 0,0725 & 0,0680 \\
\hline \multirow[t]{6}{*}{$\mathrm{CH}_{4}$} & Solar & 0,0012 & 0,0018 & 0,0016 & 0,0015 \\
\hline & Pembakaran Kayu & 0,0000 & 0,0000 & 0,0000 & 0,0000 \\
\hline & Minyak Residu & 0,0302 & 0,0305 & 0,0313 & 0,0290 \\
\hline & Pembakaran Plastik & 0,0000 & 0,0195 & 0,0179 & 0,0000 \\
\hline & Limbah Cair & 0,0530 & 0,0707 & 0,0819 & 0,0946 \\
\hline & Total & 47,3815 & 53,4217 & 53,5435 & 45,7901 \\
\hline
\end{tabular}


Tabel 5 menunjukkan bahwa untuk satuan emisi $\mathrm{CO}_{2}$-eq/ton garam kina, minyak residu menyumbangkan emisi tertinggi. Minyak residu merupakan sumber energi penggerak mesin-mesin di PT SIL. Penggunaannya sebagai bahan bakar utama menjadikan kuantitas penggunaan minyak residu di PT SIL terpakai dalam jumlah yang besar. Peringkat rata-rata sumber GRK dari yang tebesar di PT SIL adalah, minyak residu, listrik, pembakaran plastik, solar, ampas kina, pupuk, limbah cair, dan serasah.Pembakaran kayu disini dianggap karbon netral, karena proses masih berada di dalam perkebunan. Sehingga memperhitungkan penyerapan karbon dari tanaman.

\subsection{Interpretasi Hasil Penurunan Dampak Lingkungan}

Alternatif 1 Pemanfaatan ampas kina menjadi briket

Perbaikan proses dilakukan dengan menganalisis data analisis dampak. Berdasarkan analisis yang dilakukan diketahui ampas kina yang dihasilkan dari produksi garam kina sangat banyak, tetapi tidak dimanfaatkan. Sehingga ampas kina mempunyai peluang untuk dimanfaatkan. Ampas kina dapat diubah menjadi briket. Briket merupakan bahan bakar alternatif yang menyerupai arang dan memiliki kerapatan yang lebih tinggi. Briket merupakan salah satu bahan bakar yang dalam proses pembuatan atau segi bahan baku yang digunakan tergolong sederhana dan mudah untuk dilakukan, sehingga berpotensi untuk dikembangkan.

Menurut Nirwana et al. (1984) briket dari ampas kina PT SIL mengandung nilai kalor sebesar $2926 \mathrm{kal} /$ gram. Pembuatan briket dengan memanfaatkan limbah seperti ampas kina dapat menjadi alternatif dalam melakukan analisis perbaikan dalam rangka mengurangi dampak lingkungan serta menghasilkan energi alternatif. Dengan menggunakan asumsi data tahun 2015 serta data pembuatan briket oleh Nirwana et al. (1984), maka 125.06 ton ampas kina dengan nilai kalor 2926 kal/gram maka dihasilkan briket sebesar 131.642 ton dan energi yang dihasilkan sebesar $1.612 \mathrm{TJ}$. Perubahan dampak yang dihasilkan dapat ditunjukkan pada Tabel 6.

Tabel 6. Perubahan dampak GRK tahun 2015 dari

\begin{tabular}{lr}
\multicolumn{2}{c}{ pemanfaatan ampas kina } \\
\hline Data & GRK (ton $\mathrm{CO}_{2}$-eq/ton) \\
\hline Realisasi & 53.5435 \\
Interpretasi & 53.4710 \\
Perubahan dampak & 0.0725 \\
& \\
Persentase (\%) & 0.14 \\
\hline
\end{tabular}

Tabel 6 menunjukkan bahwa dengan pemanfaatan limbah ampas kina menjadi bahan baku pembuatan briket dapat menurunkan emisi GRK sebesar 0.0725 ton $\mathrm{CO}_{2}$-eq/ton garam kina. Hal ini menunjukkan bahwa dengan melakukan alternatif ini, selain dapat menurunkan dampak lingkungan sertajuga dapat menghasilkan energi alternatif sebesar $1.612 \mathrm{TJ}$.

\section{Alternatif 2 Penggantian minyak residu dengan solar}

Perbaikan proses dilakukan dengan menganalisis data analisis dampak. Berdasarkan analisis yang dilakukan diketahui minyak residu merupakan sumber terbesar penghasil emisi dalam proses produksi di PT SIL. Minyak residu merupakan bahan bakar boiler sebagai sumber energi penggerak mesin - mesin produksi. Pada alternatif ini dibahas mengenai perubahan dampak yang terjadi apabila minyak residu diganti dengan solar (IDO). Untuk itu aternatif ini sebagai upaya mengurangi dampak emisi. Berdasarkan perhitungan yang dilakukan, perubahan dampak minyak residu menjadi solar (IDO) dapat dilihat pada Tabel 7.

Tabel 7. Perubahan dampak GRK tahun 2015

\begin{tabular}{lr}
\hline \multicolumn{1}{c}{ Data } & GRK (ton $\mathrm{CO}_{2}$-eq/ton) \\
\hline Realisasi & 53.5435 \\
Intepretasi & 47.1917 \\
Perubahan dampak & 6.3518 \\
Persentase & 11.9 \\
\hline
\end{tabular}

Dengan melakukan penggantian bahan bakar energi boiler, ternyata dapat menurunkan dampak GRK sebesar 6.3518 ton $\mathrm{CO}_{2}$-eq/ton garam kina atau penurunan sebesar $11.9 \%$.

\section{Kesimpulan}

Berdasarkan hasil penelitian yang dilakukan maka kesimpulan yang diperoleh yaitu proses input output dari data inventori yang dianalisis didapat dua proses yang dilewati oleh produk kina. Pertama proses budidaya kina di PTPN VIII, dan proses produksi kina di PT SIL.

Hasil analisa LCA yang dilakukan, diketahui untuk meproduksi 1 ton garam kina menghasilkan dampak lingkungan berupa emisi GRK sebesar 47.3815 ton ton $\mathrm{CO}_{2}$-eq/ton gatam kina pada tahun 2013, pada tahun 2014 emisi GRK meningkat sebesar 53.4217 ton $\mathrm{CO}_{2}$-eq/ton garam kina. Pada tahun 2015 menghasilkan emisi GRK sebesar 53.5435 ton $\mathrm{CO}_{2}$-eq/ton garam kina dan pada tahun 2016 emisi GRK turun menjadi 45.7901 ton $\mathrm{CO}_{2}$-eq/ton garam kina.

Pembuatan briket dapat menurunkan emisi GRK pada tahun 2015 sebesar $0.14 \%$ dan menghasilkan energi alternatif sebesar $1.612 \mathrm{TJ}$. Selain itu alternatif yang juga dapat dilakukan adalah dengan mengganti penggunaan minyak residu menjadi solar (ID0). Penggantian minyak residu dengan menggunakan solar (IDO) pada bahan bakar boiler dapat menurunkan GRK sebesar $11.9 \%$ atau sebesar 6.3518 ton ton $\mathrm{CO}_{2}$-eq/ton garam kina. 


\section{DAFTAR PUSTAKA}

[BPS] Badan Pusat Statistik Jawa barat, 2018. Jawa Barat Dalam Angka 2018. Jakarta (ID) : Badan Pusat Statistik.

Curran M. 1996. Environmental Life Cycle Assessment. New York (US): McGraw-Hill.

[DISBUN] Dinas Perkebunan Jawa Barat. 2013. Indonesia Raja Kina dalam Koran Pikiran Rakyat 31 Juli 2013 [Internet]. [Diunduh 10 Juli 2017]. Tersedia pada http://disbun.jabarprov.go.id/index.php/artikel/de tailartikel/27

Ekvall T, Weidema BP. 2004. System boundaries and input data in consequential life cycle inventory analysis. Int J of LCA. 9(3): 161-171.Stasionary Combustion. USA (US): Washington DC.

[IPCC] Intergovernmental Panel on Climate Change. 2006. IPCC Guidelines

for National Greenhouse Gas Inventories Vol.2: Energy; Chapter Stasionary Combustion. USA (US): Washington DC

[ISO] International Standards Organization 14040. 2006a. Environmental

Management, Life Cycle Assessment, Principles and Framework. Switzerland (CH): Geneva.

[ISO] International Standards Organization 14044. 2006b. Environmental

Management, Life Cycle Assessment, Principles and Framework. Switzerland (CH): Geneva. Management, Life Cycle Assessment, Principles and Framework. Switzerland (CH): Geneva.
[KLH] Kementerian Lingkungan Hidup. 2012. Pedoman Penyelenggaraan Inventarisasi GRK Nasional. Kementerian Lingkungan Hidup Republik Indonesia.

Lin L, Voet EVD, Huppes G. 2009. Life cycle assessment and life cycle costing of bioethanol from sugarcane in Brazil. Ren and Sust Enr Rev. 13: 1613- 1619.

Mattson B, Sonesson U. 2003. Environmentally-friendly foof processing. Cambridge (GB): Woohead Publishing Limited.

Nirwana Aprianita, Joseph J Pardede, Tiurlan F Hutajulu, 1984. Pemanfaatan Limbah Ekstraksi Kulit Kina. Bogor (ID) : BBIHP Bogor

Purwaningsih IW. 2016. Penilaian daur hidup (Life cycle assessment) Gula Tebu di PG Subang, Jawa Barat. Bogor (ID): IPB

Putt DPS, dan Bhatia P. 2002. Working 9 to 5 on Climate Change : An Office Guide Washington D.C (US) : World Resourse Institute.

Rukaesih A. 2004. Kimia Lingkungan. Yogyakarta (ID) : Penerbit Andi.

[Setkab RI] Sekretariat Kabinet Republik Indonesia. 2011. Peraturan Presiden Nomor 61 tahun 2011 tentang Rencana Aksi Nasional Penurunan Emisi Gas Rumah Kaca. Jakarta (ID): Setkab RI

Zustika DS. 2013. Telaah Kandungan Kimia Ekstrak NHeksana Daun Kina (Chinchona Ledgeriana) . Tasikmalaya (ID) :Jurnal Kesehatan Bakti Tunas Husada 